\title{
Study of Information content Economic Value Added in Explain new models based on Free Cash Flow (CVFCFF and CVFCFE)
}

\author{
Meysam Kaviani \\ Department of Accounting, Lahijan Branch, Islamic Azad University, Lahijan, Iran \\ Email: meysamkaviani@gmail.com, MA_kimt@yahoo.com_phone: +989351488917
}

Received: June 01, 2013 Accepted: June 14, 2013 DOI: 10.5296/ijafr.v3i1.3767

\begin{abstract}
Free Cash Flow (FCF) is one of the measures based on cash flow for measuring performance of firms, among various evaluation measure of performance; that indicates the cash of firm after doing necessary expenditures for keeping and developing properties. Due to that, various models based on FCF have been explained for evaluation of firms in which free cash flow to firm (FCFF) and Free Cash Flow to Equity (FCFE) can be considered as the important ones.

This paper aims to give new models of Free Cash Flow. These models are called Created Value from Free Cash Flow to Firm (CVFCFF) and Created Value from Free Cash Flow to Equity (CVFCFE) that purpose of examined the content of information Economic value Added (EVA) of Iran Companies in explain of CVFCFF and CVFCFE. For this purpose a sample of 10 companies representing in the automotive of industry for a period of five years from 2005-2009 have been analyzed.

The Research results indicate that there is significant relationship and positive between CVFCFF and CVFCFE with Economic value Added.
\end{abstract}

Keywords: EVA, FCF, CVFCFF, CVFCFE 


\section{Macrothink}

\section{Introduction}

Creation value of people and institutions that are looking for their interests in the organizations plays a basic role in managing new organizations. Among beneficiaries, shareholders are in special situation, as their basic role in entrepreneurship and forming the institute and risk taking. The value is made for the shareholders, through valuing for other beneficiaries of the organization; and management art is incorporating and giving a balance to Creation value for a group of beneficiaries, in a way that the shareholders will get their expected values and find continuing to invest in the firm suitable, finally (Nikoomaram \& Asgari, 2009). Therefore, investors and financial managers expect to obtain the information related to benefits, cash status of the institute, income potential, suitable growth if the firm and risk analysis though reliable measure; in a way that choosing a criterion to evaluate the suitable performance and controlling the firm and gaining the goals of the firm by using the criterion leads to make evaluating the performance, suitably, important.

So, important accounting variables like sale, profit and percentage of profit to sale have been used in many firms traditionally, to evaluate the firm performance. Though these measures are used practically, but are not suitable measure to evaluate managers' performance; as a section profit relates to investing rate, closely; and none of these traditional methods consider investing price (Kaviani, 2012). Since the measure based on accounting profit are manipulating, most analysts claim that the measure based on cash flow are less distorting, so that cash flows are used in current valuation model of cash flow popularly. In next sections, new models based on FCF are introduced.

\section{Cash Flow from Operating (CFO) and FCF}

CFO on cash flow statement shows firm's ability to produce cash flows. However, majority of financial analysts argue that CFO are funds that not only should be invested in new fixed assets to enable firms to keep current level of operating activities, but in addition a proportion of that fund should be allocated as a dividend or share-repurchase to satisfy shareholders. Therefore, cash flows from operating, on its own, can't be considered as a firm ability to produce the cash flows (Bhundia, 2012). Also is the CF it generates from its normal operations-producing and selling its output of goods or services. A variety of definitions of $\mathrm{CFO}$ can be found in the financial literature. $\mathrm{CFO}$ is defined in Equation 1 (www.aw.com/gitman):

\section{$C F O=$ EBIT-Taxes - Depreciation (1)}

The firm's FCF represents the amount of cash flow available to investors - the providers of debt (creditors) and owners - after the firm has met all operating needs and paid for investments in net fixed assets and net current assets. It is called "free" not because it is "without cost" but because it is "available" to investors. It represents the summation of the net amount of cash flow available to creditors and owners during the period. FCF can be defined by Equation 2. 
$F C F=C F O-$ Net fixed asset investment (NFAI)

-Net current asset investment (NCAI) (2)

The net fixed asset investment (NFAI) can be calculated as shown in Equation 3.

NFAI=Change in net fixed assets - Depreciation (3)

Looking at Equation 3, we can see that if the depreciation during a year is less than the decrease during that year in net fixed assets, the NFAI would be negative. A negative NFAI represents a net cash inflow attributable to the fact that the firm sold more assets than it acquired during the year. The final variable in the FCF equation, net current asset investment (NCAI), represents the net investment made by the firm in its current assets.

"Net" refers to the difference between current assets and spontaneous current liabilities, which typically comprise accounts payable and accruals. (Because they are a negotiated source of short-term financing, notes payable are not included in the NCAI calculation. Instead, they serve as a creditor claim on the firm's FCF.) Equation 4 shows the NCAI calculation (www.aw.com/gitman).

NCAI=Change in current assets - Change in spontaneous current liabilities (Accounts payable +Accruals) (4)

\section{FCFF and FCFE Calculations}

There are two ways of using cash flows for the Discount Cash Flow (DCF) valuation. You can either use the FCFF which is the cash flow that is available to debt- and equity holders, or you can use the FCFE which is the cash flow that is available to the firm's equity holders only.

When using the FCFF, all inputs have to be based on accounting figures that are calculated before any interest payments are paid out to the debt holders. The FCFE in contrast uses figures from which interest payments have already been deducted. Applying the FCFF as base for the analysis will result in the enterprise value of the firm, using the FCFE will give the equity value. Since an acquirer usually takes over all liabilities, debt and equity, the FCFF is more relevant than the equity approach (Steiger, 2008).

The basic idea is that we can arrive at FCFF by starting with one of four different financial statement items (net income, EBIT, EBITDA, or CFO) and then making the appropriate adjustments. Then we can calculate FCFE from FCFF or by starting with net income or CFO.

Calculating FCFF from net income. FCFF is calculated from net income as:

$F C F F=N I+N C C+[\operatorname{Int} \times(1-\operatorname{tax}$ rate $)]-F C \operatorname{Inv}-W C \operatorname{Inv}(5)$

Where:

NI = net income 
$\mathrm{NCC}=$ noncash charge 2013, Vol. 3, No. 1

Int $\quad=$ interest expense

FCInv = fixed capital investment (capital expenditure)

WCInv $=$ working capital investment

Calculating FCFF from EBIT. FCFF can also be calculated from earnings before interest and taxes (EBIT):

$F C F F=[E B I T \times(1-$ tax rate $)]+$ Dep $-F C I n v-W C I n v(6)$

Where:

$\mathrm{EBIT}=$ earnings before interest and taxes

Dep $\quad=$ depreciation

Calculating FCFF from EBITDA. We can also start with earnings before interest, taxes, depreciation, and amortization (EBITDA) to arrive at FCFF:

$F C F F=[E B I T D A \times(1-$ tax rate $)]+($ Dep $\times$ tax rate $)-F C \operatorname{Inv}-W C I n v(7)$

Where:

EBITDA= earnings before interest, taxes, depreciation, and amortization

Calculating FCFF from CFO. At last, FCFF can also be estimated by starting with CFO from the statement of cash flows:

$F C F E=C F O-[$ Int $\times(1-$ tax rate $)]+F C \operatorname{Inv}(8)$

Where:

$\mathrm{CFO}=$ cash flow from Operating

Calculating FCFE from FCFF. Calculating FCFE is easy once we have FCFF:

$F C F E=F C F F-[$ Int $\times(1-$ tax rate $)]+$ net borrowing $(9)$

Where:

Net borrowing $=$ long- and short-term new debt issues - long- and short-term debt repayments

Calculating FCFE from Net Income. We can also calculate FCFE from net income by making some of the usual adjustments. The two differences between this "FCFE from net income" formula and the "FCFF from net income formula" are (1) after-tax interest expense is NOT added back and (2) net borrowing is added back.

$F C F E=N I+N C C-F C I n v-W C I n v+$ net borrowing $(10)$

Calculating FCFE from CFO. Finally, we can calculate FCFE from CFO by subtracting out fixed capital investment (which reduces cash available to shareholders) and adding back net borrowing (which increases the cash available to shareholders). 
$F C F E=C F O-F C I n v+$ net borrowing (11)

\section{Valuation of firm with FCFF and FCFE}

We're going to use the typical discounted cash flow technique for FCF valuation, in which we estimate value today by discounting expected future cash flows at the appropriate required return. What makes this complicated is that we'll end up with two values we want to estimate (firm value and equity value), two cash flow definitions (FCFF and FCFE), and two required returns [weighted average cost of capital (WACC) and required return on equity]. The key to nailing this question on the exam knows which cash flows to discount at which rate to estimate which value. So that in valuation models, if cash flow is expressed by FCFE, the required return on equity will be decreased as a discount rate. According to the fact that FCFF indicates payable cash flow to shareholders and lenders, the applied discount rate should depends on share risk and the loan. Therefore, weighted average cost of capital is used as interest rate.

The weighted average cost of capital is the required return on the firm's assets. It's a weighted average of the required return on common equity and the after-tax required return on debt.

Required Return to Equity (also called cost of Equity) is the Return that Shareholders expect to obtain in order to feel sufficiently remunerated. The Required Return to Equity depends on the interest rates of long-term treasury bonds and the firm's risk

The required return on equity is the sum of the interest rate of long-term Treasury bonds plus a quantity that is usually called the firm's risk premium:

Required Return to Equity = return of long-term treasury bonds + risk premium

Or Required Return to Equity is calculated through balanced models like Capital Asset Pricing Model (CAPM) and Arbitrage Pricing Theory (APT).

For example, you can see the value of the firm through Single-Stage model of FCFE and FCFF, which states the difference of two equations with various interest rates.

\section{Single-Stage FCFF Model}

The single-stage FCFF model is analogous to the Gordon growth model discussed in the previous topic review on dividend valuation models. The single-stage FCFF model is useful for stable firms in mature industries. The model assumes that (1) FCFF grows at a constant rate $\mathrm{g}$ forever, and (2) the growth rate is less than the WACC.

The formula should look familiar; it's the Gordon growth model, with FCFF replacing dividends and WACC replacing required return on equity.

Value of the firm $=\frac{F C F F_{1}}{W A C C-g}=\frac{F C F F_{0}(1+g)}{W A C C-g}$ 
Where:

$\mathrm{FCFF}_{1}=$ expected free cash flow to the firm in one year

$\mathrm{FCFF}_{0}=$ starting level of FCFF

g $\quad=$ constant expected growth rate in FCFF

WACC $=$ weighted average cost of capital

The WACC is the weighted average of the rates of return required by each of the capital suppliers (usually just equity and debt).

The WACC is one of the most important input factors in the DCF model. Small changes in the WACC will cause large changes in the firm value. The WACC is calculated by weighting the sources of capital according to the firm's financial structure and then multiplying them with their costs. Therefore the formula for the WACC calculation is (Steiger, 2008):

$W A C C=\left(\right.$ we $\left.\times r_{e}\right)+\left[w_{d} \times r_{d} \times(1\right.$-tax rate $\left.)\right](13)$

Where:

$\mathrm{w}_{e}=\frac{\text { Market val ue of equity }}{\text { Market val ue of equity }+ \text { Market val ue of debt }}$

$\mathrm{w}_{d}=\frac{\text { Market value of debt }}{\text { Market value of equity }+ \text { Market val ue of debt }}$

\section{Single-Stage FCFE Model}

The single-stage constant-growth FCFE valuation model is analogous to the single-stage

FCFF model, with FCFE instead of FCFF and required return on equity instead of WACC:

$$
\text { Value of th Equi } \frac{F C F E}{r-g}=\frac{F C F \not(1+g)}{r-g}
$$

Where:

$\mathrm{FCFE}_{1}=$ expected free cash flow to equity in one year

$\mathrm{FCFE}_{0}=$ starting level of FCFE

g $\quad=$ constant expected growth rate in FCFE

$\mathrm{r} \quad \quad=$ required return on equity 


\section{Macrothink}

\section{Free Cash Flow Yield}

We can use the FCF number and divide it by the value of the firm as a more reliable indicator. Called the FCF yield, this gives investors another way to assess the value of a firm that is comparable to the Price to Earnings (P/E) ratio. Since this measure uses FCF, the FCF yield provides a better measure of a firm's performance. The most common way to calculate FCF yield is to use Equity Market Value as the divisor. The Equity Market Value of a listed firm is the firm's Market Value that is each share's price multiplied by the number of shares. The increase of Equity Market Value (EMV) in one year is the Equity Market Value at the end of that year less the Equity Market Value at the end of the previous year. The Equity Market Value is also called as Capitalization.

The formula is:

Free Cash Flow Yield $=\frac{\text { Free Cash Flow }}{\text { Equity Market Value }}$

FCF yield is similar to share return essentially, that is provided through dividing cash dividend each share (calculated based on Generally Accepted Accounting Principles (GAAP) to price per share. Usually, the lower ratio leads to fewer attractions for investing. Its logic states that investors would like to get the highest profit from the lowest price.

Some investors knows FCF (that is provided by considering investment expenditures and other necessary ones for continuing the activity) as the most accurate measure for yield, therefore FCF yield is preferred to share return.

So that, through replacing FCF yield per share is measured by FCFE and FCFF to Free Cash Flow to Firm Yield and Free Cash Flow to Equity Yield.

Changing the growth rate in FCF and the risk of cash flow fluctuations in a time space should be considered as an essential factor. According to the relation between FCFE and FCFF and its nature to Cash Flow from Operating of the firm can be used in the equation.

Free Cash Flow to Firm Yield $=\frac{\text { Free Cash Flow to Firm }}{\text { Equity Market Value }}$

$$
\text { Free Cash Flow to Equity Yield }=\frac{\text { Free Cash Flow to Equity }}{\text { Equity Market Value }}
$$

Yield ratios based on FCF include much many content of information in various investing decisions; and most analysts claim that cash flow of the firm is manipulated less than other measure based on accounting profits like each share interest. 


\section{Macrothink \\ International Journal of Accounting and Financial Reporting \\ ISSN 2162-3082 2013, Vol. 3, No. 1}

\section{CVFCFF and CVFCFE}

As mentioned, the discount rates that is used for valuating based on FCFE and FCFF, are different; that is, if FCFE valuation models are used, the cost of equity will be applied and if the valuation model is FCFF, the used discount rate will depend on share risk and loan; so weighted average cost of capital is used as interest rate.

Therefore, to create the value in a time space based on FCFE and FCFF models, the yields of free cash flow to firm and free cash flow to equity should be more than cost of capital and cost of equity in the firm, respectively; so the created value from the models based on FCF (created value of the firm in one year) is obtained when the firm performance increases more than expected. These models have been suggested by Meysam Kaviani (2013) and are calculated through following equations:

$C V F C F F=E M V_{t} \times\left[\left(F C F F_{t+1} / E M V_{t}\right)-W A C C\right]$

Or

$C V F C F F=F C F F_{t+1}^{-}\left(E M V_{t} \times W A C C\right)$

Where:

CVFCFF $=$ Created Value from Free Cash Flow to Firm

EMV $_{\mathrm{t}}=$ Equity Market Value at the beginning of the year

$\mathrm{FCFF}_{\mathrm{t}+1}=$ Free Cash Flow to Firm in one year

WACC = weighted average cost of capital

And also:

$\left.C V F C F E=E M V_{t} \times\left[\left(F C F E_{t+1} / E M V_{t}\right)-r\right)\right]$

Or

$C V F C F E=F C F E_{t+1}^{-}(E M V t \times r)$

Where:

CVFCFE $=$ Created Value from Free Cash Flow to Equity

EMV $_{\mathrm{t}}=$ Equity Market Value at the beginning of the year

FCFE $_{t+1}=$ Free Cash Flow to Equity in one year

r

$=$ Required Return to Equity 


\section{Economic Value Added (EVA)}

EVA predicts firm's generated incomes by comparing operational profit after tax with total cost of capital (debt and equity) (Stewart, 1991). Eva is a performance indicator that properly counts with the ways leading to increase or loss of firm's value. The traditional accounting performance indicators such as Return on Equity (ROE) and Return on Assets (ROA) due to their inadequacy in giving direction to decision makings and solution finding have been always subject to criticism, especially, since they didn't take cost of the invested capital into account and as the management guiding tools in value creation they suffered serious shortcomings. In addition, these indicators fall short of representing firm's real performance.

In calculation of EVA, cost of capital includes all financing costs of the business unit, both interest rates and shareholders expected rate of return, all of which are manifested in the WACC. EVA is calculated by the following general formula:

$\mathrm{EVA}_{\mathrm{t}}=\mathrm{NOPAT}_{\mathrm{t}}-\mathrm{WACC}\left(\right.$ Capital $\left._{\mathrm{t}-1}\right)$

In which;

$N O P A T_{t}=$ Net Operational Profit after Tax in the end of period $t$

WACC = Weighted Average Cost of Capital

Capital $_{t-1}=$ Total capital book value in the beginning of period $t$ (the end of period ${ }_{t-1}$ )

EVA is primarily used for general supervision on firm's value creation. EVA is not a strategy, but a method by which results are measured. Stern Stewart and coworkers (1980) propose EVA as a management decision making tool. It should be noted that Alfred Sloan, director general of GM, did not know the exact term, yet since 1920's EVA concept has been something familiar to him, meanwhile accountants at the time knew about RI which was a concept close to EVA. RI is in fact a value which is left over after payment of return on equity and interest. However, EVA was a far more seriously proposed and developed concept by financial and economic experts and scholars, to the extent that today it is considered indispensible as an indicator of firm's value.

\section{Literature Review}

In the early 1990s, the relationship between FCF and business financial performance had been studied in the word. Baskin's study showed that a firm's profitability was negatively correlated to its debt ratio. It was said that the higher the firm's profitability, the lower its debt levels. The results did not support one of the points of views in the theory of FCF that by controlling debt effect corporate performance could be enhanced (Baskin, 1989).

Some papers also evaluated the relationship between performance measures and market value added (MVA). For example, Fingan (1991) demonstrated that there is significant association between MVA and EVA comparing to other performance measures such as EPS, cash flows, 
capital growth and ROE.

O'Byrne (1996) investigated the relationship between EVA, earnings measures and FCF, and the share return. He reported that earnings measures unlike EVA have significant association with the share return.

Milunovich and Tseui (1996) found that MVA is more highly correlated with EVA than with Earnings per Share (EPS), EPS growth, Return on equity (ROE), FCF or FCF growth.

Goetzmann and Garstka (1999) found that long-term survival of companies may be related to accounting earnings, and more, simple EPS does as well or better than EVA at explaining differences across companies and at predicting future performance.

Turvey et al. (2000) studied the relationship between EVA and share market returns for a sample of 17 publicly traded food firms in Canada. The key finding was that no relationship could be found between the two.

Gunther, Landrock and Muche (2000) in examining the Germany stock market, could not prove that value-based measures (EVA, Cash Value Added (CVA), DCF and Tobin's Q) outperform traditional accounting-based measures (Return On Sale (ROS), Return On Assets (ROA), and ROE).

Worthington and West (2001), using pooled time-series, cross-sectional data on 110 Australian companies over the period 1992-1998, proved that relative information content tests reveal earnings to be more closely connect to returns than NCF, RI and EVA.

Some researchers investigated EVA from valuation aspect. For example Shrieves and Wachowicz (2001) examined EVA, FCF and net present value (NPV) to show that which measure has greater power from valuation aspect. They documented that all the measures have same power for valuating.

Some researchers examined different measures. For example, Worthington and West (2004) investigated the accounting measures (earnings before extraordinary items (ERN) and net cash flows from operations (NCF)) and economic measures (residual income (RI) and EVA) to find out which variable has the largest relative information content. Their research was on 110 Australian firms over the period 1992-1998 and they showed that EVA has the largest relative information content among others.

As result, there is no agreement among the researches about the best performance measures but from quantitative point of view, Sharma and Kumar (2010) argue that there are less numbers of studies that do not show the superiority of EVA among other measures in developed country.

\section{Hypotheses}

1. There is a significant relationship between EVA and Created Value from Free Cash Flow to Firm (CVFCFF) in Automotive of industry Iran Stock Exchange. 


\section{Macrothink}

International Journal of Accounting and Financial Reporting

ISSN 2162-3082

2. There is a significant relationship between EVA and Created Value from Free Cash Flow to Equity (CVFCFE) in Automotive of industry Iran Stock Exchange.

\section{Research method}

Given the thinness of the Iranian capital market, this study uses all publicly traded firms on Iranian stock exchange during the period of 2005-2009. Data base on records of financial statements and market data of all Iranian firms that are listed on Automotive Industry Iran Stock Exchange, and that are subject to the regulations by the Capital Market Authority in Iran. Listed firms were then screened against several factors; and remaining firms were then tested for availability of financial data during the test period (2005-2009). This screening yielded a final sample of 10 firms.

\section{Methodology}

The relationship between CVFCFF and CVFCFE with EVA was tested by the following regression models:

$$
\begin{aligned}
& \text { CVFCFF }_{\text {it }}=\beta_{0}+\beta_{1} E V A_{i t}+\beta_{2} \operatorname{SIZE}_{i t}+\beta_{3} L E V_{i t}+\beta_{4} G R O W T H_{i t}+\varepsilon_{i t} \\
& \mathrm{CVFCFE}_{\mathrm{it}}=\beta_{0}+\beta_{1} \mathrm{EVA}_{i t}+\beta_{2} \operatorname{SIZE}_{i t}+\beta_{3} L E V_{i t}+\beta_{4} \text { GROWTH }_{i t}+\varepsilon_{i t}
\end{aligned}
$$

Where:

\section{Dependent variables are:}

$\mathrm{CVFCFF}_{\mathrm{it}}=\mathrm{Created}$ Value from Free Cash Flow to Firm for firm I in year $\mathrm{t}$

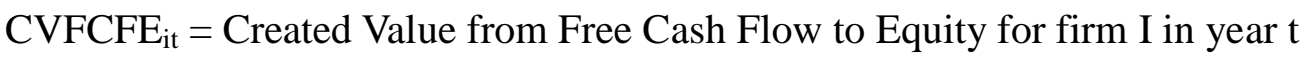

\section{Independent variable is:}

$\mathrm{EVA}_{\mathrm{it}}=$ Economic Value Added for firm I in year $\mathrm{t}$

\section{Control variables are:}

$\mathrm{SIZE}_{\mathrm{it}}=$ Natural logarithm of Total assets for firm I in year $\mathrm{t}$

$\mathrm{LEV}_{\text {it }}=$ Total debt to Total Assets for firm $\mathrm{I}$ in year $\mathrm{t}$

GROWTH= growth opportunities as measured by Tobin's q (Tobin's q is calculated by dividing the market value of a firm by the replacement value of the book equity)

$\varepsilon_{\mathrm{it}}=$ the error term. 


\section{Macrothink \\ International Journal of Accounting and Financial Reporting \\ ISSN 2162-3082 \\ 2013, Vol. 3, No. 1}

\section{Testing of Hypothesis and Regression results}

Table 1 shows correlation between the research variables at 0.01 and 0.05 significance. As is observed, the obtained results from Spearman Correlation Test indicates direct and significant correlation of CVFCFF and CVFCFE with Economic Value Added (EVA), i.e. with increase in EVA, CVFCFF and CVFCFE are expected to increase as well. In addition, the obtained results from this test do not confirm significant correlation of investment growth opportunities with the measures CVFCFF and CVFCFE, while there are significant correlation between of firm size with CVFCFE and leverage with CVFCFF.

\section{<TABLE 1 HERE>}

In regard to the first hypothesis which is formulated to examine presence of any significant association between EVA and the indicators CVFCFF and CVFCFE, given the obtained Durbin-Watson statistic (1.98) for the first model which lies between 1.5 and 2.5 (table 2), the null hypothesis suggesting absence of any auto-correlation between the errors (residual terms) is confirmed. Thus, the regression equation, if present, is applicable. Further, using ANOVA (analysis of variance) the model reliability is examined. Given that F (Sig.) is smaller than 0.05 , the assumption on linearity of the relationship between the variables is confirmed. In other words, the model is reliable and there is a significant relationship between EVA and CVFCFF. The obtained coefficient of determination $\left(\mathrm{R}^{2}\right)$ for the model is 0.802 indicating 80.2 percent of the changes in the dependent variable are explained.

\section{$<$ TABLE 2 HERE >}

According to the above regression data and statistical test data, it can get the relationship between CVFCFF and EVA as follow regression equation:

$\mathrm{CVFCFF}=2.260 \mathrm{E}-6 \mathrm{EVA}+\square \square \varepsilon$

Table 3 presents the second model which examines presence of a significant relationship between EVA and the CVFCFF. Given the obtained Durban - Watson statistic for this model (1.904) which lies between 1.5 and 2.5, the null hypothesis suggesting absence of auto-correlation between errors (residual terms) is confirmed. Thus, the regression equation, if there is any, can be applied. The obtained F (Sig.) from ANOVA is smaller than 0.05, so the assumption on linearity of the relationship between variables is confirmed. It means that the model is reliable and there is a significant relationship between EVA and CVFCFE. $\mathrm{R}^{2}$ for the model is 0.796 , which means 79.6 percent of changes in the dependent variable are explained 
by EVA.

\section{<TABLE 3 HERE>}

According to the above regression data and statistical test data, it can get the relationship between CVFCFE and EVA as follow regression equation:

\section{$\mathrm{CVFCFE}=1.813 \mathrm{E}-7 \mathrm{EVA}+\square \square \varepsilon$}

\section{Conclusion}

By looking at the basis of performance evaluation, it is found that the necessity to use more accurate measure is felt more than before, while scientific progresses and human evolution can be seen; in a way that investors and financial managers expect to investigate the information about real profit of the institute, cash state of the institute currently and in future, revenue potential, sustainable development of the firm and risk analysis through reliable measure, nowadays. Therefore, new measures have been proposed for evaluating the performance that can cover common weaknesses in last measure and be a reliable evaluation tool in decision making by investors.

The research results suggest use of EVA by decision makers as one of the new predictors of FCF, since, today, company managers are required to adopt a new economic framework in their organization which reflects value and profitability more adequately. Hence, finding an indicator capable to reveal firm performance with a relatively reasonable certainty is an imperative, because lack of a suitable instrument for performance evaluation has been one of the main reasons for failure of the efforts made by the managers who were interested in enhancing their organization performance.

Considering the main focus of this research, as was found, a merely higher EVA necessarily goes along with a higher CVFCFF and CVFCFE, hence, use of EVA as interpreter and predictor of CVFCFF and CVFCFE is recommended to company managers. Therefore, in a condition where there is no sufficient information base for calculation of CVFCFF and CVFCFE, EVA can satisfactorily serve investors and decision makers in interpreting the information content conveyed by the two new indicators. Despite the poor general knowledge of the capital market regarding CVFCFF and CVFCFE due to their recent introduction to the literature and the financial world, they are used for the information they convey on shareholder value added from perspective of free cash flow. Moreover, the findings on correlation of the new indicators with EVA further support application of CVFCFF and CVFCFE as reliable indicators of Crated value for Shareholder. The importance of this finding lies in the fact that companies in the Iranian capital market for creation of shareholder value need an FCF return greater than cost of capital and required investor rate of return.

In this article, giving the models based in FCF can eliminate the distorting effects of the measure based in profit and it is expected that they are examined with other evaluating 
measure in traditional and novel performance to make practical, financial and investment decision, in various studies.

\section{Reference}

Baskin: An Empirical Investigation of the Pecking Order Hypothesis, Financial Management (1989), p.26.

Bhundia, A. (2012). A comparative study between free cash flows and earnings management. Business Intelligence Journal, Vol.5 No.1, 123-29.

Fingan, M. (1991). Extension of the EVA and MVA applications. Financial Analysts Journal, $1(1), 554-556$.

Goetzmann, W. N. and S. J. Garstka. (1999). the Development of Corporate Performance Measure: Benchmarks Before EVATM, Yale ICF Working Paper, 99-06, July 12, New Haven: Yale School of Management.

Gunther, T., B. Landrock and T. Muche. (2000). 'Genwing versus Unternehmenswertorientierte performance - Eine Empirics Untersuchung auf Basis der correlation von Kapitalmarktrenditen für die Deutsche DAX-100 -Unternehmen' [Profit versus Value Based Performance Measures. An Empirical Investigation Based on the Correlation with Capital Market for German DAX-100 Companies], Controlling, 1(2), pp. 69-75 and 2(3), pp. 129-134.

Kaviani, M. (2012). "Study of and explain the relationship between the Financial Leverage and new Performance Metrics (EVA, MVA, REVA, SVA, CVA): Evidence from Automotive Industry Tehran Stock Exchange". Thesis of financial management, Islamic Azad University, Science and Research Branch, Tehran, Iran.

Nikoomaram, H. \& Asgari, M.R. (2009). Proposing a Model for Predicting Tehran Stock Exchange Output Using REVA, EVA, EP and EPS metrics. http://www.sid.ir.

O'Byrne, S. F. (1996). EVA and market value. Journal of Applied Corporate Finance, 9, 116 25. http://dx.doi.org/10.1111/j.1745-6622.1996.tb00109.x

Shrieves, E. R., \& Wachowicz, M. J. (2001). Free Cash Flow (FCF), Economic Value Added (EVA TM), And Net Present Value (NPV): A Reconciliation Of Variations Of Discounted-Cash-Flow (DCF) Valuation. The engineering economist, 46(1). http://dx.doi.org/10.1080/00137910108967561

Steiger F. (2008). The Validity of Firm Valuation Using Discounted Cash Flow Methods Seminar Paper, 1-25.

Turvey, C. G., L. Lake, E. Van Duren and D. Sparing. (2000). 'The Relationship between Economic Value Added and the Stock Market Performance of Agribusiness Firms', Agribusiness, 16(4), pp. 399-416.

Worthington, A., \& West, T. (2004). Australian Evidence Concerning the Information Content of Economic Value Added. Australian Journal of Management, 29(2), 201-242. 
http://dx.doi.org/10.1177/031289620402900204

Worthington, A.C. \& West, T. 2001, 'Economic value-added: A review of the theoretical and empirical literature', Asian Review of Accounting, vol. 9, no. 1, pp. 67-86.

http://dx.doi.org/10.1108/eb060736

www.aw.com/gitman

http://www.investopedia.com

Table 1: The results of Correlations Matrix for Dependent and Independent Variables

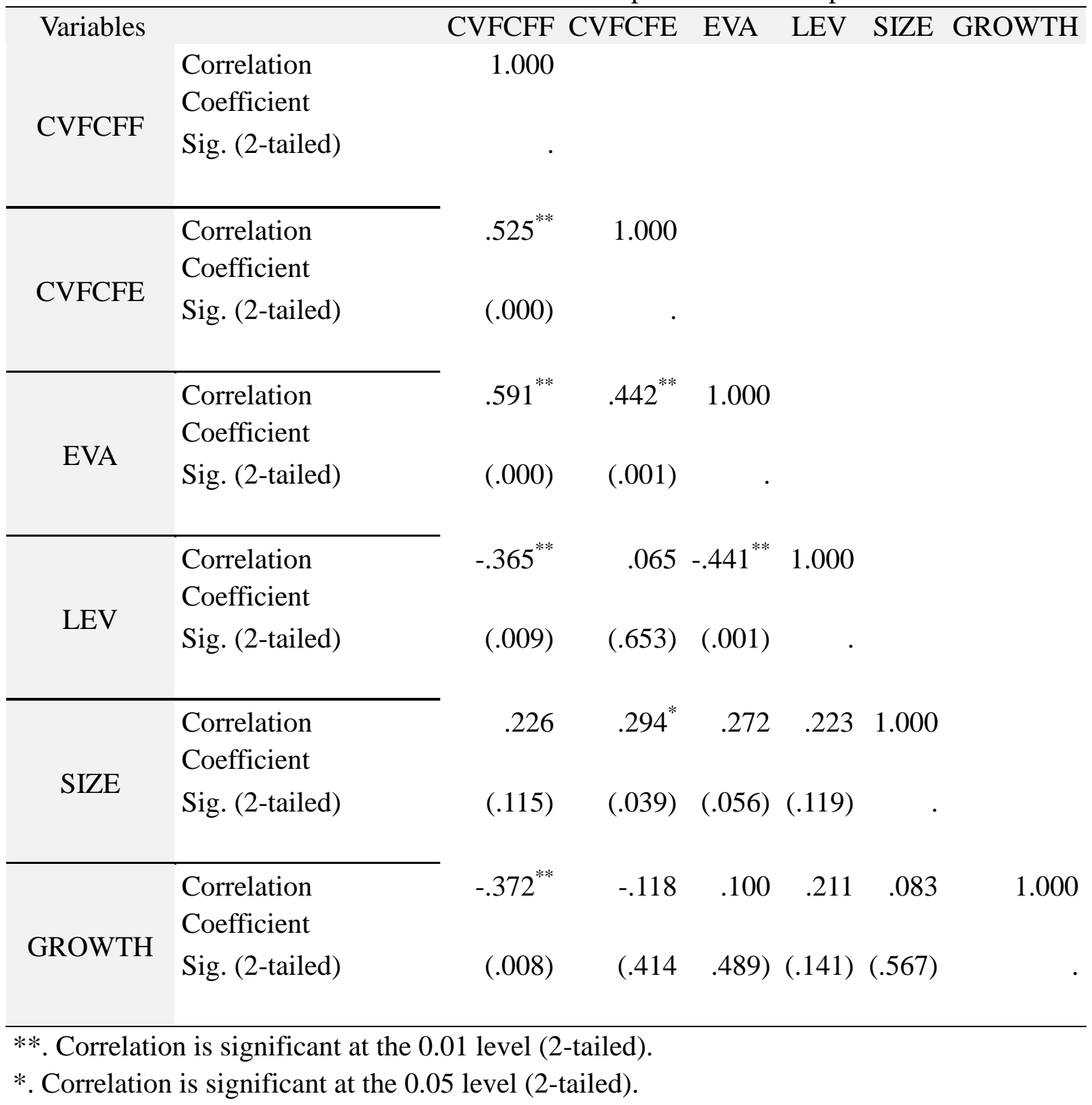




\section{Macrothink \\ International Journal of Accounting and Financial Reporting \\ ISSN 2162-3082 \\ 2013, Vol. 3, No. 1}

Table 2: The results of the analysis for Model 1

\begin{tabular}{|c|c|c|c|c|c|}
\hline Variable & $\mathrm{B}$ & Std. Error & $\mathrm{t}$-Statistic & Sig. & Durbin-Watson \\
\hline Consent & 1193315.808 & 4736132.975 & .252 & .802 & \multirow{5}{*}{1.981} \\
\hline EVA & $2.260 \mathrm{E}-6$ & .000 & 9.349 & .000 & \\
\hline Ln Asset & 478442.771 & 1916027.030 & .250 & .804 & \\
\hline LEV & -14012.240 & 183275.023 & -.076 & .939 & \\
\hline GROWTH & -1128197.799 & 687797.321 & -1.640 & .108 & \\
\hline $\mathrm{R} 2$ (Adj. -R2) & \multicolumn{5}{|c|}{$.802(.785)$} \\
\hline F (Sig.) & \multicolumn{5}{|c|}{$45.683(.000)$} \\
\hline
\end{tabular}

Predictors: (Constant), EVA, SIZE , LEV, GROWTH

Dependent variable: CVFCFF

Table 3: The results of the analysis for Model 2

\begin{tabular}{l|c|c|c|c|c}
\hline \multicolumn{1}{c|}{ Variable } & B & Std. Error & t-Statistic & Sig. & Durbin-Watson \\
\hline Consent & -1145555.817 & 3956890.139 & -.290 & .774 & \\
\hline EVA & $1.813 E-6$ & .000 & 8.977 & .000 & \multirow{2}{*}{1.904} \\
\hline Ln Asset & 1223794.101 & 1600780.320 & .764 & .449 & \\
\hline GROWTH & 51357.118 & 153120.517 & .335 & .739 & \\
\hline LEV & -924427.056 & 574633.029 & -1.609 & .115 & \\
\hline R2 (Adj. -R2) & \multicolumn{5}{c}{$.796(.778)$} \\
\hline F (Sig.) & \multicolumn{6}{c}{$43.860(.000)$} \\
\hline
\end{tabular}

Predictors: (Constant), EVA, SIZE , LEV, GROWTH

Dependent variable: CVFCFE 